\title{
The Theological Misappropriation of Christianity as a Civilizing Force
}

\section{Sabrina D. MisirHiralall}

To cite this article: Sabrina D. MisirHiralall (2017) The Theological Misappropriation of Christianity as a Civilizing Force, Journal of Research on Christian Education, 26:2, 79-104, DOI: 10.1080/10656219.2017.1331413

To link to this article: http://dx.doi.org/10.1080/10656219.2017.1331413

Published online: 16 Aug 2017.

Submit your article to this journal $\llbracket$

View related articles ๘

View Crossmark data \lceil 


\title{
The Theological Misappropriation of Christianity as a Civilizing Force
}

\author{
Sabrina D. MisirHiralall \\ Educational Foundations Department, Montclair State University, Montclair, NJ, USA
}

\begin{abstract}
The theological misappropriation of Christianity as a civilizing force occurs when individuals convert to Christianity due to deception that ignores the faith-based aspect of Christianity. The history of Western education in India illustrates the hidden curriculum that Christian missionaries employed to disrupt the Indian educational system. This unnerving pedagogy points to the need for a postcolonial theoretical framework that relates the inescapable hybridity of religion and culture where Orientalism has the potential to occur. To press the ongoing urgency of this discussion, I convey how the history of British India connects to my lived-reality as an American Hindu. Overall, I point to hybridity as a lived paradox of ambiguous conflict that embraces interfaith relations. I offer implications for Christian missionaries today to foster authentic interfaith connections without engaging in colonizing ideologies.
\end{abstract}

At the Mid-Atlantic Region of the American Academy of Religion (MAR-AAR) conference one year, I met a Catholic theologian whose belief in Christ sparked my interest. In the past, I encountered many people who seemed to ignore my identity as a faith-based Hindu and instead aim to proselyte me into Christianity. My colleague at MAR-AAR was different because he was interested in learning about my identity as a faith-based Kuchipudi (Suresh, 2003), Indian classical Hindu dancer, and he also shared his identity as a Catholic respectfully. Through this encounter, I began to explore Christianity within the research world.

Soon, I gravitated towards Catholic services as I developed a love for Jesus Christ that resonates with the Catholic tradition. As a graduate student at Montclair State University, I began to attend mass weekly at the Newman Catholic Center, where Father Jim taught me the daily mysteries. I could not partake in Communion because I was not baptized as a Catholic. Yet, tears would fill my eyes during Communion, as I would watch others partake. I faced ambiguity because of my lived paradox as I found myself to be a faith-based Hindu who genuinely had a desire to partake in a sacred Christian 
ritual because of a strong belief in Jesus Christ. Someone once told me that I should go to a Protestant Church because all are permitted to partake in Communion regardless of baptism. However, I would not do so because, after exploring many avenues of Christianity, I felt that this action would offend the Catholic tradition, which I believe in. I soon realized that Catholicism focuses on love for humanity as opposed to forcefully proselyting in the name of Christ.

As a faith-based Hindu, I believe in One Supreme Being who manifests in different forms at different times for different purposes. Hinduism (Vidyarthi, 1988 ) is a monist religion where One Supreme Being manifests in many different forms. Thus, I believe in Jesus Christ as a manifestation of the One Supreme Being who manifested in a particular form, at a particular time, with a particular purpose. This set of beliefs often creates ambiguous conflict for me because many do not comprehend how I as a faith-based Hindu could believe in Christ. Christians often say that I am not a true believer because if I were, I would only believe in Christ. My Hindu family and friends often worry that my gravitation towards Christianity would cause me to lose myself as a Hindu. Yet, my soul feels spiritually rejuvenated whether I attend Catholic Church or Hindu Mandir ${ }^{1}$ as I sincerely pray.

At any rate, many Hindus welcomed the missionaries of British India who shared their beliefs in Christ. In fact, some Hindus adorned their homes with murtis $^{2}$ of Christ and even performed puja (worship) onto Christ just as they would perform puja to Hindu murtis. Unfortunately, some of the missionaries of British India were not interested in embracing the religious identity of Hindus through interfaith connections. Instead, these missionaries wished to deceptively proselyte Hindus into converting to solely Christianity. Here, I refer to missionaries of the Catholic, Protestant, Baptist, Calvinist, Anglican, Wesleyan, and Presbyterian tradition (Piggin, Bogue, Buck, \& Smith, 1984; Potts, 1967; Singh, 1990). Because of the varying denominations of Christian missionaries in British India, I will use the term Christianity to refer to missionaries regardless of denomination.

The Global Dictionary of Theology points to different types of missionary typology.

Jacques Dupuis (1998): "Ecclesiocentrism" suggest religions are not salvific in themselves, rather a personal response of faith is needed to the church's proclamation of the gospel. "Christocentrism" refers to an inclusive approach according to which Christ is the Savior but the benefits of saving work may be found outside the Christian Church and Christian religion. "Theocentrism" is the pluralistic paradigm according to which Christ is one Savior among other savior figures and not an exclusive one (Dyrness \& Kärkkäinen, 2008).

These missionary approaches do not endorse Christianity as a civilizing force that needs to colonize the world. On the contrary, these approaches respect non-Christian religions that uphold humanistic principles. I urge 
Christian missionaries to consider one of these missionary approaches to uphold the theological integrity of Christianity. Christian missionaries should not dishonor Christianity by misusing the religion with deceptive methods of conversion to serve primarily social and political agendas. Thus, I request Christian missionaries to reflect on the theological purpose of Christianity with integrity as they move forward with educating non-Christians about Christianity and exploring faith-based conversion.

Missionaries who use deceptive means for conversion ignore the religious identity of Hindus in a manner that endorses theological misappropriation. It is my contention that theological misappropriation occurs when religions or religious practices are used for the primary purpose of social and political agendas. Christianity was often theologically misappropriated as a civilizing force in British India and is sometimes still misappropriated today. This misappropriation is problematic because missionaries who forcefully employ Christianity theologically dishonor the very tradition they claim to represent. Theological misappropriation often ignores the individual's authentic spiritual connection to the manifestation of the Supreme Being. In other words, someone who converts to Christianity does not need to believe in Jesus Christ to identify as Christian. As long as the individual participates in Christian religious rituals, the individual is seemingly Christian. In many cases, theological misappropriation dismisses the individual's religious belief in the religious rituals that accompany the tradition. It is imperative to maintain awareness for the theological misappropriation of religion for social and political purposes.

The history of British India points to the troublesome way that some Christian missionaries ignored the sacredness of the Christian tradition and instead focused on personal and political agendas. This history presents an issue of concern for Christian missionaries who wish to help non-Christians explore their connection to Christianity from a theological perspective. There were some Christian missionaries who had a genuine interest in a missionary approach that was sensitive to the needs of Indian society in British India. These missionaries engaged in humanitarian outreach to provide basic education, medical services, social welfare services, charity services, pastoral services, and contemporaneous relief services in an effort to help those within Indian society (Singh, 1990, p. 237). Singh indicates that many Indians respected this approach to missionary work in India:

Indian people have been a lover of the social and spiritual Gospel of Christianity and of its value to Indian life and thought but they regard conversion not only as most obnoxious but also consider it often short-lived and skin-deep, and, in many cases a disguised function of colonialism. They do not cast their votes in favour of such Christian missionaries who make attempt to convert the Indian people into their own faith. Nevertheless, they love, regard and venerate those Christian missionaries who preach the dignity of humanity in such a lofty strain as Hinduism (Singh, 1990, p. 312). 
Many Indians across the nation were grateful for these services that focused more on the common threads of humanitarianism as opposed to the forceful conversion to Christianity.

In this article, I engage in a dramatic philosophical plea to prevent the theological misappropriation of Christianity as a civilizing force. I shed light on this topic as I turn to a postcolonial theoretical framework to relate the inescapable hybridity (Bhabha, 1994) of religion and culture where Orientalism (Said, 1978/1979) has the potential to occur. The long history of Western education in India illustrates the hidden curriculum that Christian missionaries employed to disrupt the Indian educational system that had a history of its own beyond Western antiquity. To press the ongoing urgency of this discussion, I will share a profound interfaith experience that I had with an Anglican priest at the University of South Carolina Aiken (USCA). This interfaith interaction prompted me to confront a colonizing gaze from an Evangelical Christian who I also met at USCA. Overall, I point to hybridity as a lived paradox of ambiguous conflict that embraces interfaith connections. As I relate the history of British India that connects to my lived-reality as a faith-based American Hindu, I offer implications for Christian missionaries today to foster authentic interfaith connections that honor the individual without engaging in colonizing ideologies filled with social and political agendas.

\title{
Postcolonial theoretical framework
}

Before continuing, I must briefly relate the postcolonial theoretical framework that influences this project. I will begin with Edward Said (1978/1979) who coins the term Orientalism as he points to the way false knowledge develops misrepresentations of religions and cultures and in turn further misconceptions. Said writes

\begin{abstract}
The idea of representation is a theatrical one: the Orient is the stage on which the whole East is confined. On this stage will appear figures whose role it is to represent the larger whole from which they emanate. The Orient then seems to be, not an unlimited extension beyond the familiar European world, but rather a closed field, a theatrical stage affixed to Europe. An Orientalist is but the particular specialist in knowledge for which Europe at large is responsible, in the way that an audience is historically and culturally responsible for (and responsive to) dramas technically put together by the dramatist (Said, 1978, p. 63).
\end{abstract}

Overall, Said's notion of Orientalism focuses attention on how the West often confines the East to rigid boundaries where the East becomes what the West wishes the East to be. This confinement is a farce of a theatrical space where some Easterners mock their very own Eastern religion and culture as they dramatically fulfill the theatrical desires of the West, which causes an imagined version of Eastern religions and cultures to develop. Simultaneously, this places Western religions and cultures on a pedestal as real. 
As a faith-based Hindu who believes in Christ, I face the ambiguity of my lived paradox in this space where East meets West. I face difficulty because I must maintain fidelity to who I am as a faith-based Hindu as I embrace the Christian faith with respect. For example, clothing for each respective venue differs significantly. The attire for Hindu mandir includes clothing almost the entire body. I usually wear a saari (Banerjee \& Miller, 2003) with a piece of shawl to cover my head as I pray. On the contrary, the dress code for Catholic mass, in today's society, does not seem to require the clothing of the full body. I often wear fitted knee-length dresses and leave my hair down as I kneel in prayer.

I noticed that I as I sit cross-legged in a Hindu mandir with my hands clasped by my chest and my eyes closed as I sing chants and slokas, ${ }^{3}$ I feel that my soul lifts from my body and moves into a spiritual abode where One Supreme Being manifests to shower me with Divine blessings. Similarly, as I kneel during a Catholic mass in prayer with my hands clasped to my chest, my eyes closed, and my head bent, I feel that my soul raises to a spiritual realm where One Supreme Being again manifests to shower me with Divine blessings. I do acknowledge that clothing is a representation of our cultural background and often is symbolic. However, in religious settings, I respectfully move with sensitivity beyond clothing as I focus on a connection to One Supreme Being through prayer. Overall, clothing is a lived paradox for me because I am Eastern and Western simultaneously.

The binary of the West and the East is problematic because it creates this illusionary boundary that does not exist. Yet, Said is forced to use the terms West and East because humankind has segregated themselves into these illusionary binaries to make a distinction between the way we live and the way they live. This prevents society from the urgent interreligious dialogue needed to develop interfaith and intercultural interactions that concentrate on the way we are all interconnected, regardless of whether Western or Eastern. I do not wish to mock Hinduism or become what the West demands me to be. Nevertheless, religion and culture does not remain static. Therefore, there is a need to move beyond the cultural boundaries of East and West and into a space of sensitive interfaith connection.

I must point to Homi Bhabha (1994) who focuses his attention on hybridity as the inevitable way that cultures are entangled.

Hybridity is the sign of the productivity of colonial power, its shifting forces and fixities; it is the name for the strategic reversal of the process of domination through disavowal (that is, the production of discriminatory identities that secure the "pure" and original identity of authority). Hybridity is the revaluation of the assumption of colonial identity through the repetition of discriminatory identity effects. It displays the necessary deformation and displacement of all sites of discrimination and domination. It unsettles the mimetic or narcissistic demands of colonial power but reimplicates its identifications in strategies of subversion that turn the gaze of the discriminated back upon the eye of power. For the colonial hybrid is the 
articulation of the ambivalent space where the rite of power is enacted on the site of desire making its objects at once disciplinary and disseminatory-or, in my mixed metaphor, a negative transparency (Bhabha, 1994, p. 112).

Bhabha does not refer to an international culture of supremacy where one religion or culture reigns supreme over the other. Instead, Bhabha illustrates the importance of a third space as a place to explore the inevitable entanglement of religion and culture as a part of a global society. Here, cultures do not remain in isolation from one another. On the contrary, there is an intercultural interaction that causes cultures to enter the unavoidable space of hybridity. An ethic of responsibility needs to be present in the space of hybridity as religion and culture interact. Without an ethic of responsibility, there is a danger of supremacist ideals that further colonization along with the misrepresentation of culture. My lived paradox forces me to ask myself what it means to live as a faith-based Hindu in an undeniable interreligious and intercultural world. As I explore this question, I turn to relate the legacy of my Indian ancestors.

\section{Western education in India}

There is a long history of how Western education developed in British India. The British aimed to overturn the Guru/shishya system and replace it with Western education. The Guru/shishya (Ratnam, 2013) Hindu system provided education in India since ancient times. Despite this, the British overlooked this system as a viable method of education. During the colonial era in British India, Western education was often synonymous with the concealed goal to provide Christian teachings.

Initially, education was a matter for the East India Company, which ran India until the Mutiny of 1857. Thereafter, education became the responsibility of the Indian Government based in Calcutta, which was, in turn, answerable to the India Office in London. In reality the day-to-day administration of education was devolved to the various Indian provincial governments. In 1921, constitutional changes brought about by the Government of India Act of December 1919 resulted in provincial governments being popularly elected for the first time and henceforth assuming formal responsibility for most aspects of education policy (Whitehead, 2005, p. 318).

At first, the private joint-stock East India Company (Golant, 1975) controlled Western education in British India whose curriculum included Oriental culture and science (Whitehead, 2005). The educational system maintained religious neutrality, which prevented the governmental endorsement of Christian missionary education. Some members of the Supreme Council of the East India Company believed that Indians should learn their own religion and culture as opposed to adopting a Western system, which is why the council endorsed religious neutrality. With religious neutrality in mind, the British claimed that the main goal was to develop a trading empire 
that focused on commerce. This notion of religious neutrality is problematic because it points to mere tolerance as opposed to genuine appreciation. Moreover, the government endorsed the "us" versus "them" mentality as they isolated Westerners from Easterners. This endorsement created a division that did not embrace the interfaith connections that were necessary for a harmonious society.

Drawing on the explanations of Viswanathan (1989, p. 80), the British government maintained that it did not teach Christianity, but yet there were several Christian references in English education. There was a hidden agenda to impart Christian scriptural teachings that would serve to lead Indians to convert to Christianity.

If not in quite the same colorful terms, other missionaries pointed out that though the government claimed it taught no Christianity, a great deal was actually taught, for English education was so replete with Christian references that much more of scriptural teaching was imparted than generally admitted (Viswanathan, 1989, p. 80).

It is evident that this hidden curriculum aimed to destroy Hinduism and universalize Christianity. Orientalists such as Jones (Jones \& Murray, 2006), Colebrooke (Colebrooke \& Colebrooke, 1873), and Charles Wilkins (Wilkins, 1830) felt obligated to reintroduce Indians to Indian heritage. At any rate, after the Charter Act of 1813 (Webster, 1990) of the East India Company, Christian missionaries were permitted, after a long banishment, to preach Christianity in India. This is where Christian missionary education (Murdoch, 1899) developed in India.

From a theological perspective, it was deceptive to use concealed methods to push Indians to convert to Christianity. This deceptive method paid little attention to the complexity of interreligious contact. In one regard, the introduction of Christianity in India opened the eyes of Indians to Christianity as a valid world religion. In another, the introduction of Christianity in India caused Christian missionaries to engage in dominant behaviors that oppressed Hinduism. In turn, this prevented a harmonious interreligious dialogue in a space of hybridity that had the potential to foster humanistic relations.

To continue, Thomas Macaulay's Minute on Indian Education (Macaulay \& Woodrow, 1862) refuted religious neutrality in 1835 as Macaulay pointed to the so-called need to uplift the heathens. It is important to note that the term heathen refers to anyone who is not baptized or does not believe in Christ. The underlying implication speaks to the need to civilize Indians. Macaulay convinced the majority of the council that a Western educational system serves to civilize Indians. Moreover, the council believed that they had a responsibility to educate Indians. William Bentinck, Governor-General of India in 1835, endorsed the English Education Act of 1835 (Viswanathan, 1989, pp. 43-45) with the goal to reallocate funds from the East India Company for a Western education of Indians. 
A few years before this political decision, Alexander Duff (Vermilye \& Presbyterian Church in the U.S.A, 1890) diagnosed India with a so-called problem when he arrived in 1830. Christian missionaries were only successful with securing converts to Christianity from the lower Indian castes but were unsuccessful with the Indian middle and elite classes. For this reason, Duff prescribed the need for an educational system that would attract the middle and upper classes in his schools. He developed an educational reform plan (Emmott, 1965) that would appeal to the middle and upper classes that wished to maintain their status. They were told that they would gain upward mobility through employment in the Western governmental system (Viswanathan, 1989, p. 164).

The British used the Hindu caste system (Jois, 2002) to their advantage as they created an alliance with the indigenous elite who became displaced in British India. They expected the indigenous elite of the upper classes to persuade the middle and lower classes to pursue British educational opportunities, which as mentioned earlier was infused with Christian references. The upper classes were told that these supposed opportunities would teach Indians about different cultures in an effort to create a more harmonious society. The Western education system validated a hidden curriculum (Giroux \& Purpel, 1983) that served to control the education of Indians who became public servants to the British despite the longstanding Indian traditions. The British aimed to stratify Indian classes through education that would create a middle class to initiate social change, according to Western ideals, as a part of an imperialist economy (Viswanathan, 1989, p. 146). Indians were taught by the British to emulate European ideals as it pertained to the land of India and Indian people.

My issue concerns the uncritical method used to deceptively persuade Indians to convert to Christianity for status in society. I view Christianity as a philosophical world religion that endorses critical thought as part of Christian ethics. Yet, some missionaries overlooked the need to teach Indians in a straightforward manner about Christianity with conversion in mind. On the contrary, these missionaries did not pay attention to the authentic relationship between Indians and Christ, but rather was just focused on enforcing a Christian worldview for the purposes of managing the society.

The educational reform eventually included a curriculum (Viswanathan, 1989, pp. 62, 70, 129-132) that taught English literature, Western history, and endorsed Christianity as a valid religion, while rejecting Hinduism as a fictitious myth. William Carey (Carey \& Carter, 2000) compared the Mahabharata, a Hindu epic that endorses Hindu ethics, to the Iliad by Homer (Viswanathan, 1989, p. 105). Carey believed that readers needed to use a literary lens to read both texts, and detested the fact that Hindus had faith in the Mahabharata as Divine authority of history. Unlike Carey, Alexander Duff saw no comparison between the Hindu epics and Western literature. 
Duff made a distinction between Western literatures that came from a literary tradition versus the Hindu epics that were read by Hindus as a part of Divine authority (Viswanathan, 1989, p. 109). The educational reform system of British India had a goal to change the Hindu epistemological system to a Western epistemological framework that used a Western lens to read the Hindu epics as mythology as opposed to a Divine authority that stimulated ethical thinking. The British made a distinction between the Hindu epics that they believed pretended to relate history as opposed to Western literature that used imagination non-pretentiously.

Aside from the genre of literature that the British placed the Hindu epics in, the British had a moral issue at stake. With morality in mind, the British desecrated the Hindu texts because they felt the texts were a source of immorality (Viswanathan, 1989, p. 6). For example, the British could not understand why Draupadi had five husbands, who were brothers, in the Mahabharata (Vyāsa, 2004) In her past life, Draupadi performed penance to Shivaji, a manifestation of the Supreme Being. Draupadi asked for the boon of five characteristics in her future husband. She asked for a husband who is the epitome of Truth, has incredible strength, is an ace archer, most handsome, and is patient. Shivaji explained to Draupadi that it is difficult for a mortal man to have all of these character traits. Nevertheless, to fulfill Draupadi's wishes, Shivaji granted her request. Thus, Draupadi married the five Pandava brothers who each exemplify the character traits she desired in a husband (Vyāsa, 2004). The British lacked the epistemological framework to comprehend the depth of Draupadi's marriage to the five Pandava brothers. At any rate, the British began to develop poor translations that could not reconcile the structure of Eastern writings with a Western literary style. Indian children were taught that the Hindu scriptures were mythology and not a part of a historical tradition of India (Viswanathan, 1989, p. 110). Western educators wished to destroy the faith-based Hindu epistemological framework that Indians had. An imagined Hinduism began to take shape as the West began to reshape the Hindu literary tradition.

The underlying premise points to the acceptance of a supreme Western, epistemological framework. My main concern here is that some of the British dismissed any critical examination of Hinduism as a viable world religion. Instead, these individuals focused on dismantling the Hindu epics so that these epics would make sense. Here, instead of aiming to learn about the Hindu epics from a Hindu epistemological perspective to understand Hindu ethics, the British labeled Hindus as delusional, heathens who needed to be civilized.

Essentially, the educational reform of the time was based on the view of India, Indians, and Hinduism. Many of the council members of the East India Company believed Indians were sinful beings who could not comprehend the difference between decency and indecency, due to the mental capability of their native mind that caused a lack of understanding. Moreover, the council 
members believed the Hindu texts taught impurities that caused the need for the British to intervene and morally regenerate Indians as a part of society. The British saw Indians as humans with a low intellectual capacity with minds adequate for minor trade but not governmental administration, especially because of their so-called unstable, volatile nature. Yet, the British resisted endorsing Christian missionary work in India because of the fear that threatened Indians would rebel.

Thus, the British used the disguise of a liberal education to trick Indians into believing that they would gain empowerment with the advancement of upward mobility. Eventually, obedient Indians were admitted to governmental positions-not for the purpose of governing but rather to fulfill the orders of the British bureaucracy (Viswanathan, 1989, p. 69). The British manipulatively appropriated Indian land as a part of the goal to increase territorial control. It is unfortunate that the British saw India as fertile soil for engaging in experimentation that observed and recorded the progress of colonial conquests that aimed to acquire land and civilize Indians (Viswanathan, 1989, pp. 25, 65).

Indians unveiled the disguise that prompted a national response to the fears of missionary endeavors that aimed to colonize rather than phenomenologically share the theological aspect of Christianity that honors interfaith interaction. For this reason, the Raigarh State Conversion Act of 1936 required Indians to submit an application to the government if there was a desire to convert religions (Jenkins, 2008). Although India became a secular state in 1976 when the Constitution (Constitution of India, 2015) was amended, there is still a sense of fear that provokes religious intolerance (Radhakrishnan, 1993) as each religious group feels the need to protect its boundaries. Religious intolerance is an unfortunate residual effect of the legacy of colonization that compartmentalized India into religious groups instead of embracing the opportunity for an educational interfaith interaction. The undertaking of the British to resocialize Indians by attempting to change the previous history of Hinduism and Indian culture is the Orientalist (Said, 1978/1979) phase of British rule in India. The British began to prune the Hindu epics to get rid of their unfavorable components as they separated so-called legend from fact, which created imagined knowledge of Hinduism (Viswanathan, 1989, p. 34).

To reteach Indians with an Orientalist epistemology, the British set up colleges and universities across India. Hindu College, currently now known as Presidency University (Brief History of Presidency, 2016), was founded in 1817 followed by Sanskrit College (Sanskrit College: Home, 2016) in 1824. When originally established, Hindu College admitted boys of all castes on the contingency that they would pay five rupees per month. The students would learn the English language and literatures. In contrast, at that time, the British paid Brahmin boys a stipend to attend Sanskrit College (Viswanathan, 1989, 
p. 151). The students at Sanskrit College would relearn the Hindu epics from a Western perspective as well as grammar, law, arithmetic, and theology.

Orientalism served as a form of administration that helped the British pursue their mission in India to civilize Indians. Indian parents who realized this pursuit withdrew their children immediately from the tyranny of British education (Viswanathan, 1989. 58). Yet, missionaries aroused curiosity of Christianity in India. Some Hindus believed that Christianity consisted solely of facts to remember and not an experience that needed engagement (Viswanathan, 1989, p. 84). Eventually, Indians realized that the upward mobility that the British promised consisted of limited opportunities. There was a functionalist system in place that aimed to educate Indians to serve British imperialist needs. Some Indians humored the British by pretending to believe in Christianity and Western epistemology for the sole purpose of protecting their social privilege.

For example, Michael Madhusudan Datta ${ }^{4}$ did not accept the theological aspect of Christianity although he was baptized: “Though Dutt was himself a Christian convert, he had clearly less concern for the theological side of Christianity in this essay than with Christianity as a civilizing force" (Dutt \& Seely, 2004, p. 10). Others, such as Banerjea (Banerjea, 1861) who became Reverend Banerjee (Dutt \& Seely, 2004, p. 10), came to truly believe in Christian theology and Western epistemology as a new part of Indian religion and culture. As mentioned earlier, some Indian parents pulled their children out of school where Christianity was taught, whereas, others realized that it was either a Western education for their children or no education.

Indians who had a distinguished knowledge of European literature was promoted to offices under a resolution passed in 1844 by Lord Hardinge (Great Britain, 1909; Viswanathan, 1989, p. 84). Monier-Williams complained that the British could not overeducate Indians because then they would rebel against their assigned life position that was part of a functionalist system (Viswanathan, 1989, p. 143). The British aimed to teach English exclusively to cause the extinction of native languages and literature. There was an attempt to destroy the Indian social structure by denying the traditional authority of the upper classes. The religious caste system was reduced to an archaic institution that the British wished would decay. Christianity was the sole authority that influenced what constitutes knowledge. Missionaries missed the aesthetics of the complex Hindu epics that endorsed humanistic ethics.

Based on a sociological study by Singh (1990), Indians today appreciate the spirituality of Christianity as many respect Christians who endorse the humanitarian principles of Christianity. However, conversion is often still seen as a part of colonialism. Christian missionaries do not gain respect by endorsing conversion but rather gain appreciation from Indians by preaching Christian principles and showing Indians what it means "'to be with Jesus', 'to work with Jesus,' and 'to work like Jesus”” (Singh, 1990, p. 312). 
Many Indians embraced Christianity because of the humanistic value of the Christian tradition. However, Indians often regarded conversion as a deceptive method used to colonize India to adhere to a Western religious and cultural lifestyle. Nevertheless, some missionaries maintained a humanistic approach to missionary work that helped to provide hope through social service work.

They also have high regard for those missionaries who have imparted cheer and hope to the poor and the low man engaged themselves in social services. They also show high regard for those missionaries who harbour strong regard or cultivate an attitude of reverence to other faiths, and their religious leaders and saints (Singh, 1990, p. 312).

Missionaries were not always deceptive individuals who focused on colonizing ideologies. Some missionaries theologically lived as Christians who concentrated on the need for humanitarian action to fight the injustices of society. These types of missionaries are often forgotten in postcolonial studies.

\section{De-Orientalization}

Christian missionaries need to pursue de-Orientalized knowledge of nonChristian religions and cultures. I use the term de-Orientalize (MisirHiralall, 2015) to refer to knowledge that develops based on primary sources read from the intention of the authors of those sources. For example, a de-Orientalized reading of Hinduism includes reading the primary version of the Hindu epics with the goal to understand the epics from a Hindu epistemological perspective. Also, I use the phrase non-Christian religions and cultures to refer to religions and cultures that Christians do not believe resonate with Christianity although these seemingly non-Christian religions may maintain similar humanistic values.

Once Christian missionaries maintain a de-Orientalized epistemological framework of non-Christian religions and cultures, then they may enter a pedagogical space of hybridity (MisirHiralall, 2015). In this space, I urge Christian missionaries to engage in interreligious and intercultural contact to help non-Christians gain an authentic understanding of Christianity from a theological perspective while at the same time considering the religious and cultural identity of the individuals. There needs to be sensitivity for the ancestry and the complex social ties that surround the individual. Christian missionaries should guide the individual to engage in self-reflection to think about a relationship with a Divine Entity, family, the community, and the world at large. After critical thought and dialogue, non-Christians should decide whether or not to convert. The decision to convert is not a decision that should be made based on social, political, and personal agendas but rather needs to consider the individual's relationship to Christ. 
With the theological aspect of Christianity in mind, I also ask nonChristians to think about the theological and cultural aspect of religious traditions. Here, I will speak primarily about Hinduism since this paper points to the theological misappropriation of Christianity in India. Hinduism is not just an individual religion, but rather is a religion that has strong ties to family. Contemporary time does not consider the Yugas (time periods) of Hinduism that begins before the Roman calendar. Since ancient times in Hinduism, familial ties were a crucial part of religious worship. For example, the manifestation of Shri Rama (Tulasīdāsa \& Prasad, 1990) even points to the way a son must perform the sacred pitri (ancestral) puja for his departed father regardless of geographical location. In other words, Shri Rama performed the pitri puja while in the forest region although his father's body was miles away in the kingdom of Ayodhya. My point is that each member in a Hindu family has a theological role to fulfill not as a part of culture but as part of a religious tradition.

Hindu children fulfill the Shrad ${ }^{5}$ rites for their parents. Brothers offer the sacred Raksha Bandhan protection to their sisters. There is a list of many sanskaars (religious rites) that each family member fulfills or guides one another to engage in. Thus, if a Hindu converts to a non-Hindu religion, then the entire family system is disrupted. The Christian missionaries ruptured this system during the British era in India. Instead of this approach, missionaries should seek to share Christianity and learn about other religious traditions in search for the common thread that runs across.

The task of the missionary should be to pool his religion along with others. Perhaps the chief hope for an important deepening of self-knowledge on the port of Christendom is by way of a more thorough-going sharing of its life with the life of the Orient. The relations between religions must take increasingly hereafter the form of a common search for truth (Singh, 1990, pp. 312-313).

I am not saying that Hindus must not convert to Christianity. What I am saying is that there needs to be consideration to all of the familial aspects of Hinduism when considering such a life-changing decision that will impact on the departed ancestors and future generations to come.

Although there is an attempt to isolate religion and culture into secluded spheres, hybridity is inescapable. With a genuine interest to learn about religion in mind, there is an urgent need for sensitivity in the pedagogical space of hybridity. Hindus and Christians engaged in religious and cultural contact in British India. Some Christian missionaries learned the ancient practice of yoga in India.

It is no doubt true that today Christian Yoga has developed parallel to Indian Yoga. Now Christian Yoga is being practiced by many Catholic missionaries. Some Catholic missionaries have received formal training, under competent guidance, 
in the ancient Indian discipline of Yoga and, in turn, impart instruction in the discipline to a growing number of Christian students (Singh, 1990, p. 301).

These Christian missionaries used the main concept of Yoga, an ancient practice of Hinduism, to develop an integrative Christian Yoga practice to add to the Christian tradition. There are deep questions here such as whether or not Yoga is appropriate within the Christian tradition based on Christian views of the body. I will not delve into that issue because it is not the purpose of this article. My point is that these Christian missionaries did not aim to merely convert Hindus to Christianity. Instead, they tried to understand Hinduism, learn from Hinduism, and integrate concepts of Hinduism into Christianity to enrich the Christian tradition. My point here is that Christianity and Hinduism were not limited to isolated spheres but rather inevitably engaged in contact. Since contact is unavoidable, it is imperative to engage in interreligious dialogue to foster sensitive interfaith connections.

Pope John Paul II acknowledges the harm of some missionaries to nonChristian religions and repents for this sin. The Vatican II Council shows respect for non-Christian religions as the council relates the need to understand non-Christian religions.

\footnotetext{
Christians should not persecute or discriminate against their fellowmen because they are of another race or class or because of their non-Christian religion $(4,8)$. Rather they should treat them as brothers $(5,1)$ for the sake of Christ who died 'because of the sins of all men, so that all might attain salvation' $(4,9)$ and for the sake of God 'who is the Father of all' $(5,1)$. Because of the partial truth more or less visible in the non-Christian religions (as rays of that Truth which enlightens all men, 2, 5) these religions are to be respected as expressions of the universal longing for this truth $(1,3 ; 2,1-4)$. Therefore Christians should cultivate dialogue and joint projects with them $(2,1 ; 4,6)$. But the Church must never cease to proclaim Christ to them as the way, the truth, and the life, as the fullness of the religious life, as the one in whom God reconciled the world to himself $(2,5)$, and whose cross is a sign of God's all embracing love $(4,9)$ (Barth, 1968).
}

The term universal here does not mean supremacy. It also does not endorse the impulse to colonize. On the contrary, universal here refers to a quest to find the truth, which is a life-long search that may never have a philosophical end. Non-Christians need to understand the heart of Christians who strongly believe in Christ as the One, the Way, and the Truth. However, Christians must understand that seemingly non-Christians may believe in similar universal values though not explicitly clear to Christians. If there is One Supreme Being who manifests in different forms, at different times, and for different purposes, then this One Supreme Being may manifest in the form of Christ, Shri Krishna, Allah, Addonai, and so forth.

I believe that all of these manifestations primarily manifested in different historical eras. Although I am a faith-based Hindu who will not convert to Christianity, I wholeheartedly believe in Christ just as I believe in Shri 
Krishna. Yet, I respect the rituals of the Catholic Church that do not allow me to partake in Communion during mass since I am not baptized. I must add that many of my non-Hindu friends and colleagues also respect the Hindu rituals when they view or attend Hindu services. There is a mutual respect and love between my non-Hindu friends, colleagues, and me.

\section{Interfaith connections}

Now, I consider it necessary to share my lived paradox that is full of ambiguous conflict to reveal the difficulties that I endure as a faith-based Hindu who embraces an interfaith connection to Christianity. Here, I will point specifically to my campus visit to University of South Carolina Aiken (USCA) during Fall 2015. David Dillard-Wright invited me to present and dance for a campus-wide lecture, Experiencing Shri Ganesha Through Hindu Dance. This example has a two-fold purpose. First, it is important to note the colonizing gaze I experienced from an Evangelical Christian student. Second, it is crucial to acknowledge the interfaith encounter that I had with an Anglican priest who provides an example for Christian missionaries interested in interfaith connections.

After I completed the contemplative dressing process to transform into the dancer, Dillard-Wright and I went for a mindful walk before the lecture. As we walked the quiet campus, we saw a young man with a sign around his neck. I read the sign as Dillard-Wright and I walked past. When the student noticed me reading the sign, he began to walk behind me. He proceeded to ask, "Do you know that Jesus loves you?" I smiled and then responded, "Yes. I do know that Jesus loves me." He asked me why I was dressed the way that I was. I told him about the upcoming lecture and invited him to attend.

Although I smiled, I was not oblivious to the colonizing gaze from the student. I knew that if I stopped to talk to the student, I would open myself up to confrontation as he would attempt to convert me. However, it is precisely this confrontation that is necessary for interfaith connections. I cannot isolate myself into a protective sphere that shields myself off from non-Hindus. On the contrary, I need to immerse myself in the confrontation to share who I am as a faith-based Hindu in the hopes of sparking the opportunity for a harmonious interfaith connection that moves beyond the divisions that religious compartments create.

To continue, Dillard-Wright began the lecture as he shared excerpts from his book At Ganapati's Feet: Daily Life with the Elephant-Headed Deity before he introduced me. I then explained my epistemological framework of Hinduism. I shared that as a Hindu, I believe that One Supreme Being manifests in different forms, at different times, for different purposes. With this belief in mind, I go to Catholic mass and engage in sincere prayer to Jesus Christ. Tears often fill my eyes during the Eucharist because although I believe in Christ, I do not partake in Communion since I am not baptized. Not only 
do I attend Catholic mass, but in the past, I also accompanied my professors to synagogue where I was not just an observer but a spiritual being who engaged in prayer.

Next, I explained Edward Said's notion of Orientalism, the creation of Hindu dance, and how I engage in contemplative practices of mindfulness before, during, and after the dance. Soon I moved onto relate the dance moves of a sloka, Mangalam Ganesham, and Mushikavahana followed by the dance series, which played to a PowerPoint with timed transitions to guide the viewers. In many cases in the Mid-Atlantic and New England regions, I often feel directly connected to the viewers of the dance as we share a phenomenological experience together. However, with this small audience in the Southeast, I sensed a division. Some individuals seemed to genuinely open themselves up to an interfaith connection with me, while others seemed resistant. My sense of this division did not prevent me from moving forward with the presentation. I focused on sharing my phenomenological experience as a faith-based Hindu as I danced and connected to One Supreme Being. At any rate, one student during the question and answer session said that she is a dancer on the dance team. She said that she wishes she could put as much passion in her dances as I did in mine. This sparked a series of questions that focused on the purpose of dance. Most of the question and answer session concentrated on expressing love through phenomenology.

After the presentation and dance, Reverend Professor Beau McLaurin Davis, an Anglican priest who serves the Southeast part of the United States, approached me. We met briefly prior to the start of the lecture. Father Davis told me that he liked and respected the way I did not use the term priest to describe my brother, who is a Hindu pandit. ${ }^{6} \mathrm{He}$ said it was great that I acknowledge that the term priest has its own history and meaning. As we talked for about 30 minutes in the lecture hall, I felt that his spirit shone so brightly almost as if radiating towards me and drawing me towards him spiritually in the most beautiful, organic manner. At the end of the conversation, he asked if it would offend me to receive the blessing of Christ. I asked if there is any reason that I should be offended. He said he does not feel it would offend me because of my spirituality. I smiled and bent my head down as he gestured and blessed me. "May the Father, the Son, and the Holy Spirit always be with you." I feel that he gave me another blessing too. I was in so much joy that I feel that I could barely recollect the precious, spiritual, religious experience. After I explained to Father Davis that Hindus often touch the feet of spiritual leaders. I asked him if I may touch his feet. When he smiled as he said yes, I kneeled down on my knees and rested my head at his feet with hands clasped in a prayer posture. It was like he was constantly blessing me without attempting to convert me.

This was a profound interfaith moment that had a great impact on me phenomenologically. Here, I experienced a reciprocal moment of an interfaith 
connection where I was drawn to a spiritual divinity within a spiritual being and this spiritual being acknowledged the divinity within me. Through this encounter, I experienced the transcendence of the illusionary boundaries between religions as the interfaith encounter concentrated on the divinity within one another. Father Davis felt that I was worthy of the blessing of Christ not because he wanted to convert me but because he wished to bless me in the way he knew how. I felt such great respect for Father Davis as an Anglican priest that I wished to touch his feet in the manner in which I would touch the feet of a Hindu pandit. I did not wish to convert Father Davis to Hinduism but rather wanted to honor him as a spiritual leader in a manner that was familiar to me as a faith-based Hindu.

Hybridity is a lived paradox for me, as I must consistently reflect on how to engage in interfaith encounters. I asked myself how should I react as a faithbased Hindu with sensitivity to Christianity? Father Davis offered to bless me and as a Hindu I accepted his blessing. I responded to his blessing by touching his feet in the manner in which I would touch the feet of a Hindu pandit. My lived paradox is complex as there are no easy answers, but I do believe that I acted as a faith-based Hindu who embraced an interfaith encounter. Some may say that I was submissive as I placed my head at Father Davis's feet. I confess that submission here is both a recapitulation of an Orientalized projection of the East as submissive to the West and yet a necessary ethical action that helps to create an opening for interfaith connections. Submission is also a component of humility as Hindus honor those worthy of such honorable respect. Thus, it is a sign of respect to engage in such an interaction with someone who has great spiritual divinity.

Yet, not all individuals are capable of embracing one another in interfaith connections that foster harmonious relationships. When I arrived back to New Jersey, I received a colonizing, angry email from the student who I met in the quad before the presentation. I consider it necessary to respond to the student publicly dissecting the nearly two-page email piece by piece. This illustrates how colonization is still alive today as some Christians still aim to dominate the world through a Christian supremacy that is so far from Christianity that I hesitate to use the term Christian. I hesitate because Christianity is a beautiful religion of love as opposed to a religion of anger and hatred that bitterly aims to force all global citizens to believe in Christ.

Hello Dr. Sabrina ... This is—, the boy you saw holding the "Jesus sign" while you were in University of South Carolina Aiken prior to your presentation on religious Hindu-dance. Hope the conference on Saturday went well? I honestly wish you all the best in the academic field and also in your religious pursuits.

But if I may continue ma'am, and please forgive me if I may offend you but while you were walking around the campus of USC-Aiken, you read the Jesus poster I hung on myself, I asked and you told me you have Jesus-Christ, that you believed 
He died for your sins. But ma'am, If that were true then you wouldn't be living a lie of idol-worship, “... Who changed the truth of God into a LIE, and worshiped and served the CREATURE more than the Creator, who is blessed forever. Amen ...." (Romans.1: 24, [25], 26).

As I stated during the lecture, I believe as a faith-based Hindu that One Supreme Being manifests in different forms, at different times, for different purposes. Because I believe in One Supreme Being, I believe the Supreme Being manifests as God. Thus, I believe in Jesus Christ. I explained during the lecture that murtis (statues) are not mere idols but rather provide a focus point for devotees to spiritually focus on. The Supreme Being is beyond the comprehension of mortal human beings. Consequently, murtis serve as a concentration point for Hindus to focus spiritual energy towards in prayer to the One Supreme Being. This student did not attempt to understand this portion of the lecture, but rather insists that I engage in a "lie of idol-worship." Moreover, this student does not comprehend my relationship with Jesus Christ. As I mentioned, my epistemological framework as a faith-based Hindu causes me to believe in Jesus Christ. Not only do I believe in Jesus Christ, but I often feel Christ's right hand above me in a blessing posture when I attend Catholic mass and Hindu pujas. In many instances, I often spiritually feel Christ and Shri Krishna interchange images as I have religious experiences that point to a monist epistemological framework.

If indeed Jesus Christ is Your Lord and Savior then you would walk in His light "... I am the light of the world. Whoever follows me will never walk in the darkness, but will have the light of life." (John.8:12). But “... If we say that we have fellowship with Him, and walk in darkness, we LIE, and do not the truth ..." (1John.1:6). " ... the one who says he abides in Him ought himself to walk in the same manner as He walked." (1John.2:6)

The student assumes that I walk in darkness because I am a faith-based Hindu. Yet, many often describe me as a ray of sunshine. I often feel a spiritual glow as I move through my day. How can this be darkness if the light of my soul shines brightly? Mother Lakshmi keeps the light of my soul burning brightly, which provides me with the ability to see with clarity. If One Supreme Being lights the path, then Mother Lakshmi ${ }^{7}$ is a part of the One and so is Christ. They are all a part of a monist entity. Furthermore, Christ walked a Holy path that honored humanity. To spread hatred as this individual does as he ignores the light of my soul is to dishonor Christ, whereas to embrace love for humanity is to honor Christ.

The Lord Jesus Said it Himself "No one can serve two masters. For you will hate one and love the other; you will be devoted to one and despise the other." I say this with deepest love and respect Professor, Christianity is not a 'Religion' it is a Person and it is Christ Jesus, "Whoever confesses that Jesus is the Son of God, God abides in him, and he in God." (1John.4:15) "Therefore if anyone is in Christ, he is a new creature; the old things passed away; behold, new things have come." (2Cor.5:17). "Therefore there is now no condemnation for those who are in Christ Jesus" 
(Rom.8:1). "I am the vine, you are the branches; he who abides in Me and I in him, he bears much fruit, for apart from Me you can do nothing." (John.15:5)

It is evident that the student did not comprehend when I said that I believe in One Supreme Being. The individual assumes that I "serve two masters" without realizing that "two masters" in this sense is actually One master. The student personifies Christ without the realization that it is beyond the capacity of mortal beings to comprehend the nature of Christ. I do not sense that this student understands that Christ is not a dictator who demands followers but rather Christ is a profound religious entity beyond human comprehension.

Beloved Dr. Sabrina, Christianity is not a "Religious Belief/Belief System," it is Faith; "The assurance of Things hoped for, the evidence of things not seen" (Heb.11:1) in "religion" man seeks God through all sorts of practices, traditions and ceremonies but in Christianity, God is seeking Man. Not because man is good "... There is none who does good, not even one" (Ps.14:3) but because God is good and Loving, "This Is true Love, not that we loved God, but that He first loved us and sent His Son to be the propitiation for our sins." (1John.4:10).

On the contrary, Christianity, like many religions, is based on a faith-based religious epistemological framework. This individual dismisses rituals although rituals are an essential component to Christianity. There is a ritual for mass, communion, and baptism, for example. Religious rituals often help humans understand how to live life. In Hinduism, the ritual of puja teaches Hindus how to serve humanity not in a passive manner but with a wholehearted love that wishes to benefit humankind.

It is one thing to be in church and a very different thing to be in Christ. Many, many Preachers, ministers, deacons, Priests, Bishops, Cardinals and even Popes are just "playing church" they only practiced their religious routines, traditions and protocols but refused to accept the life giving Truth in Christ Jesus. [ ... "It is the Spirit who gives life; the flesh/ human efforts profits nothing; the words that I have spoken to you are SPIRIT and they are LIFE." (John.6: 63)]. Jesus Said, "Not everyone who says to me, 'Lord, Lord,' will enter the kingdom of heaven, but only the one who does the will of my Father who is in heaven. Many will say to Me on that day, 'Lord, Lord, did we not prophesy in Your name, and in Your name cast out demons, and in Your name perform many miracles? Then I will tell them plainly, 'I never knew you. Get away from me, you who practice evil!" (Matt. 7:23). But for those who truly Believe in Christ Jesus "Therefore there is now no condemnation for those who are in Christ Jesus" (Rom.8:1).

It is quite arrogant that this student condemns religious clergy as merely "playing church" whereas it seems to me that this individual is the one who creates a misguided farce out sacred religious quotes for his own colonizing purposes. There is a distinction here between those who engage in a genuine, religious framework that aims to embrace humankind with a love for humanity and those who employ religion as a dictatorship, which is a colonizing evil that forsakes the love of humankind. My relationship with the One 
Supreme Being causes me to realize that the Supreme Being is a forgiving entity based on intention. Therefore, if an individual unknowingly commits evil and seeks forgiveness, the One Supreme Being by nature will forgive. This epistemological framework causes me to forgive this misguided boy since I sense that he strongly believes his intentions are Christian-like. I acknowledge that he as an individual does not represent the vast majority of Christians.

The Fact remains Dr. Sabrina, you cannot say you have Jesus and also live in Hinduism. Jesus said "I am THE WAY, and THE TRUTH, and THE LIFE. No one comes to the Father except through me." Jesus was not just one of many manifestations of "Svayam Bhagavan," He is God Himself made known to us. "No one has ever seen God. But the unique One, who is himself God, is near to the Father's heart. He has revealed God to us" (John.1:18) "He is the image of the invisible God, the firstborn of all creation." (Col.1:15). "For in Christ dwells all the fullness of the Godhead bodily" (Col.2:9). "And without controversy, great is the mystery of godliness: God was manifest in the flesh, justified in the Spirit, seen of angels, preached unto the Gentiles, believed on in the world, received up into glory" (1Tim.3:16).

Earlier in the message, the student points to the term religion as he says that Christ is not about religion but is about faith. Yet the argument is flawed because the student now focuses on Jesus and Hinduism as distinctive religions. It is my contention that the term religion often causes an illusionary division that faith-based individuals are aware of as they transcend this false boundary. This student is not willing to understand a monist epistemological framework but rather insists that, "Jesus was not just one of many manifestations." The student's lack of philosophical capacity illustrates the danger of close-mindedness that refuses to comprehend the religious epistemological framework of anyone who differs although he himself maintains a dangerous religious epistemological outlook that has the potential to lead to danger. This type of perspective has the potential to lead to genocide because such closemindedness does not even want to listen and understand other perspectives. As a reminder, we do not live in a Christian world but rather we live a world of many religious traditions. For this reason, it behooves society to learn to live through interfaith connections that embrace humanity to prevent the dangers that accompany religious supremacy.

Please forgive me if I offended you, it is in love and respect I wrote this, I know how deep and devoted you are in your religious dances and lifestyle. But remember this, Jesus said "Whoever does not take up their cross and follow me is not worthy of me," (Matt.10:38) "Whoever wants to be my disciple must deny themselves and take up their cross and follow me." (Matt.16:24) "If you try to hang on to your life, you will lose it. But if you give up your life for my sake, you will save it.” (Matt.16:25).

Once Again, All the very best. Jesus loves you. Yes He does, with an Undying Love.

The student did not deny my devotion as a faith-based Hindu dancer and how that impacts on my lifestyle. Yet, the student believes that Christianity is the sole 
path that all must follow. This here is a clear example of how some individuals, who claim to be religious, theologically misuse Christianity as a civilizing force. This student wants to discipline me into conforming to a so-called Christian ideal to save my soul from sin. In one regard, I was hurt as I initially read this email as a fearful shock ran up and down my body as I imagined what my ancestors went through when colonization was at its height in British India and in Guyana. In another regard, I do feel this individual saw a light in me that compelled him to write such a long email because he felt that I already had a desire to have a relationship with Christ and he wanted to forcefully push me towards that.

As I mentioned, I had a profound interfaith moment with Father Beau Davis, an Anglican priest, who I met at the lecture. Because I felt that I needed spiritual guidance from someone who I respected as a Christian, I corresponded with Father Davis about this student's message. Father Davis ${ }^{8}$ stated:

Christ told us that there are two Commandments that we need to follow: to love God with all your heart, with all your soul, and with all your mind; and secondly to love your neighbor as yourself. This young man seems to have forgotten that second part. I have only known you for a short while, but I believe that you are an ardent follower of these two commandments. You obviously love God (our language and understanding may differ at times, but your love is true) and I witnessed you treat a room of strangers like good friends. The rest is commentary. As for what you should do: love those who persecute you. That is something that was difficult for me to undertake ... but I see the truth in it now. If you show that misguided boy mercy, then it is my understanding that you are closer to Christ than he is. However, I don't believe that responding to him will do much good either way. If it is the boy that I ran into, his thoughts are not his own yet. He is only repeating his programming. Age will teach him how to think on his own, and hopefully he will learn to love his neighbor in time.

I did not respond to the student because he did not seem to attempt to use the lecture and dance as an educational opportunity to learn about Hinduism. Moreover, I do agree with Father Davis that his thoughts are not his own. It feels that he is repeating a standard speech that is scripted and designed to convert non-Christians to Christianity. I do believe that I am close to a Supreme Being and by extension close to Christ. Father Davis's words helped to reaffirm that for me.

Interfaith interaction is how we learn to make the world better, and I think that what you are doing is the best way to go about it. You probably greatly disturbed that boy's thinking by being nice to him and showing him that Hindu faith is not some bizarre evil and its followers are not demons. Keep up the good fight. You always have a blessing from me.

I do believe that spiritual beings will embrace interfaith interaction to move beyond the illusionary boundaries of religions. We are a part of one race-the 
human race. Yet, we each are individuals with different ways of coming to know what we know and believe what we believe. It is imperative to engage in interfaith interactions that aim to understand one another's religious epistemological framework that will influence how we live with one another in society. Each religion may be a different path up the mountain that leads ultimately to One Supreme Being. I took comfort in hoping that, as Father Davis said, I disturbed the student's thinking as I shared Hinduism as a faith-based religion that is not based on evil or demonic worship. Overall, I took great comfort in knowing that Father Davis, as an Anglican priest, will always bless me because he acknowledges the spiritual divinity within me as a faith-based Hindu without attempting to convert me to Christianity.

\section{Conclusion: Interfaith interactions}

In sum, Christian missionaries must not theologically misappropriate Christianity as a civilizing force. Christianity is not a religion about a global supremacy based on social and political issues but rather is a religion about love for humanity. "To love thy neighbor," means to respect thy neighbor's religion and culture. Christians must acknowledge the hybridity of religion and culture that causes individuals of diverse backgrounds to intertwine. It is necessary to note that hybridity is not a simple solution to the problem of interfaith interactions but rather is a complex lived paradox. With this lived paradox in mind, it is imperative to ensure that Christians do not Orientalize unfamiliar religions and cultures to become what Christians would like these religions and cultures to be. History in British India illustrates how Christian missionaries employed a hidden curriculum that engaged in Orientalism and sought to convert Indians to Christianity for social and political purposes. This blatantly disregards the opportunity for interfaith interactions that embraces humanity regardless of religious or cultural background.

I emphasize the need for interfaith interactions in an inevitable hybrid space where individuals have the opportunity to learn about one another as a part of humanity. These interfaith interactions will each have their own unique struggles and complexities. However, this is necessary to endure as a part of the human race. I understand the need for Christian missionaries to spread the word of God, but this must occur with sensitivity. Instead of employing deceptive means to push non-Christians to convert to Christianity, I ask Christian missionaries to concentrate on interfaith interactions with an ethic of responsibility. Christian missionaries must not deceptively push non-Christians to convert to Christianity but rather must guide nonChristians to genuinely find themselves as theologically oriented Christians or spiritual beings.

When the student approached me at USCA in the quad, I wish he took the time to ask who I was and what my religious framework was with a 
de-Orientalized gaze (MisirHiralall, 2015) in mind. If he did, he may have had the opportunity to learn about Hindu philosophy that influences my epistemological framework, which helps me to develop my own sense of ethics that I engage in as I live in the world. He could have used the opportunity to teach me about Christianity in terms of Christian philosophy that influences his epistemological framework, which provokes him to develop his sense of ethics as he lives in the world. We could have taught each other through an interfaith interaction that might have helped us to heighten our spirituality as spiritual beings. However, this student had no interest in embracing me as a part of humanity but instead saw me as "living a lie of idol-worship". All he saw was his views and my views, probably because of the fear of the challenges that would arise from an interfaith connection.

In the beginning of this article, I point to my colleague who prompted me to develop a genuine theological love for Christianity. My colleague is an example to Christian missionaries who aim to help individuals discover the beauty of Christianity. He had a genuine interest in learning about who I am as a faith-based Hindu. He expressed his thoughts and perceptions of Hinduism to me, which was based on an Orientalized framework. We had many dialogues as I helped to de-Orientalize Hinduism, and he assisted me as I learned about Christianity from a Catholic perspective. We would send each other scriptural verses as we would dissect and discuss the philosophical implications. Soon, I began to see that Christianity is not a dangerous religion that will corrupt me but rather is a religion that blends with Hinduism since the underlying moral implications are similar. My colleague and I formed a deep bond of friendship as we learned more about each other though our lived paradox in a hybrid space. Now, I find myself in Catholic mass often as I pray to Jesus Christ as a faith-based Hindu who genuinely loves Christianity. That is because my colleague shared Christianity with me in a powerful manner that respected who I am as a faith-based Hindu as he taught me that Christianity is one path up the mountain of Divinity.

Overall, individuals need to maintain a de-Orientalized gaze (MisirHiralall, 2015) that seeks to genuinely learn about religion and culture. This creates an opportunity to engage in philosophical dialogue that moves beneath the surface in an attempt to inquire into the epistemological framework of religion and culture. Individuals should aim to learn about religion and culture through de-Orientalized sources that further philosophical inquiry. Moreover, individuals cannot just be observers observing a religious and cultural tradition. Instead, individuals need to create an opening within themselves for interfaith encounters that point to the complexities of a lived paradox in a hybrid space despite the fear of the challenges. This openness has the potential to lead to interfaith interactions that may help us acknowledge that we are a part of one race-the human race. As a part of the human race, it is 
imperative to diffuse colonizing ideologies filled with social and political agendas that dishonor the individual. Instead, we as a society need to engage in interfaith connections that move beyond the illusionary boundaries of religion as we embrace the complexities of our lived paradoxes in a hybrid space.

\section{Notes}

1. Mandir is the term used by Hindus to describe a place for community worship.

2. A murti is an image, often in the form of a statue, which helps Hindus to maintain focus during prayer.

3. A sloka is a Hindu prayer.

4. For the purposes of this project, I will use the spelling "Madhusudana Datta" because that is the way Datta's signature appears in his letters. Some scholars use the spelling "Dutt" to refer to this author. See Michael Madhusudan Datta: A sketch of his life and works. 1916. Madras: G.A. Natesan.

5. Religious worship for the souls of immediate family members who pass away, especially parents.

6. A pandit is a spiritual leader who performs pujas (religious worship services) in Hinduism.

7. Mother Lakshmi is the Hindu Goddess of Light and Prosperity.

8. I thank Father Davis for granting me the chance to share his correpsondence publicly.

\section{References}

Banerjea, K. M. (1861). Dialogues on the Hindu philosophy, comprising the Nyaya, the Sankhya, the Vedant: To which is added a discussion of the authority of the Vedas. London, UK: Williams and Norgate.

Banerjee, M., \& Miller, D. (2003). The sari. Oxford, UK: Berg.

Barth, K. (1968). Ad limina apostolorum: An appraisal of Vatican II. Richmond, VA: John Knox Press.

Bhabha, H. K. (1994). The location of culture. London, UK: Routledge.

Brief History of Presidency. (2016). Presidency university Kolkata. Retrieved January 08, 2016, from http://www.presiuniv.ac.in/web/presidency_history.php.

Carey, W., \& Carter, T. G. (2000). The journal and selected letters of William Carey. Macon, GA: Smyth \& Helwys.

Colebrooke, T. E., \& Colebrooke, H. T. (1873). The life of H.T. Colebrooke. London, UK: Trübner.

Constitution of India. (2015). The constitution of India. Retrieved January 8, 2016, from http:// lawmin.nic.in/coi/ coiason29july08.pdf.

Dutt, M. M., \& Seely, C. B. (2004). The slaying of Meghanada: A Ramayana from colonial Bengal. New York, NY: Oxford University Press.

Dyrness, W. A., \& Kärkkäinen, V.-M. (2008). J. F. Martínez, \& S. Chan (Eds.), Global dictionary of theology: A resource for the worldwide church. Downers Grove, IL: IVP Academic.

Emmott, D. H. (1965, May 01). Alexander duff and the foundation of modern education in India. British Journal of Educational Studies, 13(2), 160-169. doi:10.2307/3118336

Giroux, H. A., \& Purpel, D. E. (1983). The hidden curriculum and moral education: Deception or discovery? Berkeley, CA: McCutchan.

Golant, W. (1975). The long afternoon: British India 1601-1947. New York, NY: St. Martin's Press. 
Great Britain. (1909). East India (Parliamentary Papers): Annual lists and general index of the Parlimentary papers relating to the East Indies published during the years 1801 to 1907 inclusive. London, UK: Printed for H.M. Stationery Off., by Eyre and Spottswoode Ltd.

Jenkins, L. D. (2008). Legal limits on religious conversion in India. (Law and Contemporary Problems.). Duke University School of Law in Durham, North Carolina.

Jois, M. R. (2002). Ancient Indian law: Eternal values in Manu Smriti. New Delhi, India: Universal Law Publ. Co.

Jones, W., \& Murray, A. (2006). Sir William Jones, 1746-94: A commemoration. Clark, NJ: Lawbook Exchange.

Macaulay, T. B. M., \& Woodrow, H. (1862). Macaulay's minutes on education in India: Written in the years 1835, 1836, and 1837 and now first collected from records in the Department of Public Instruction. Calcutta, India: Printed by C.B. Lewis, at the Baptist Mission Press.

MisirHiralall, S. D. (2015). De-Orientalized pedagogy: Educating non-Hindus about Hinduism with postcolonial realities in mind. Rest of citation? New Jersey: Montclair State University in Montclair.

Murdoch, J. (1899). Missionary education in India: Its three great need: I. trained Christian teachers, II. Christian reading books adapted to India, III. Well-organised Sunday schools, addressed to Indian missionaries and missionary committees. Madras, India: Printed at the S.P.C.K. Press, Vepery.

Piggin, S., Bogue, D., Buck, C., \& Smith, S. (1984). Making evangelical missionaries 1789-1858: The social background, motives and training of British Protestant missionaries to India. Abingdon, UK: Sutton Courtenay Press.

Potts, E. D. (1967). British Baptist missionaries in India, 1793-1837: The history of Serampore and its missions. London, UK: Cambridge University Press.

Radhakrishnan, N. (1993). Gandhi's challenge to religious intolerance. New Delhi, India: Peace Publishers.

Ratnam, T. (2013). Engaging India's social history to understand and promote teacher change: Advances in research on teaching. In Author/Editor's, Teacher thinking to teachers and teaching: The evolution of a research community (pp. 527-553). UK: Emerald Group Publishing Ltd.

Said, E. W. (1978). Orientalism. New York: Vintage Books.

Sanskrit College: Home. (2016). Sanskrit college and university. Retrieved January 08, 2016, from http://www.sanskritcollege.co.in./

Singh, S. D. (1990). The Catholic missionaries of India: The sociological view. Varanasi, India: Ashok Prakashan.

Suresh, V. B. (2003). What is Kuchipudi? Chennai, India: Skanda Publications.

Tulasīdāsa \& Prasad, R. C. (1990). Shri Ramacharitamanas. Delhi: Motilal Banarsidass.

Vermilye, E. B., \& Presbyterian Church in the U.S.A. (1890). The life of Alexander Duff. Chicago: Woman's Presbyterian Board of Missions of the Northwest.

Vidyarthi, D. N. (1988). What every Hindu must know. St. Augustine, Trinidad and Tobago: Vidyarthi Nivaas.

Viswanathan, G. (1989). Masks of conquest: Literary study and British rule in India. New York, NY: Columbia University Press.

Vyāsa. (2004). Mahabharata. Ottawa: EBooksLib.

Webster, A. (1990, January 01). The political economy of trade liberalization: The East India company charter act of 1813. The Economic History Review (London), 43(3), 404-419. doi:10.1111/j.1468-0289.1990.tb00537.x

Whitehead, C. (2005, May 01). The historiography of British imperial education policy, part I: India. History of Education, 34(3), 315-329. doi:10.1080/00467600500065340 
Wilkins, C. (1830). Glossary of oriental terms. Originally annexed to the Fifth report of the Committee of the House of Commons on the Affairs of the East-India Company in 1812-13, and communicated to the House of Lords in 1830, London.

Sabrina D MisirHiralall, EdD, is a Postcolonial Philosopher of Education and Kuchipudi Indian Classical Hindu Dancer. She is the current Regional Coordinator for the Mid-Atlantic Region of the American Academy of Religion (MAR-AAR). 